Stevo Gavrić. dipl. ecc ${ }^{29}$

stručni rad:

UDK: 006.44:657.6

\title{
STANDARDI REVIZIJE
}

\section{REZIME}

Tema ovog članka jeste upoznavanje sa važnostima međunarodnih standarda revizije, odredbama Limske deklaracije, kao i međunarodnom organizacijom državne revizije (INTOSAI). Regionalne radne grupe koje su rasprostranjene na svim kontinentima promovišu ciljeve INTOSAI u svojim regijama, čime se obezbeđuje članovima mogućnost stručnoj i tehničkoj saradnji na regionalnom nivou. Da bi se sam proces revizije uspešno obavio, uz stručnost i obučenost revizora, neophodna je primena i pridržavanje standarda revizije.

Mnoge države su u zakone o reviziji javnog sektora ugradile odredbe Limske deklaracije u smislu da je u nadležnosti budžetske revizije i revizija javnih preduzeća. Primera radi 24 države u okviru Evropske Unije je u zakonima o reviziji javnog sektora u nadležnost Vrhovnih revizijskih institucija stavilo i reviziju javnih preduzeća.

Ključne reči: Limska deklaracija, Međunarodni standardi revizije, rasprostranjenost na svim kontinentima, stručna i tehnička saradnja,

\section{UVOD}

Revizija je sistematičan proces objektivnog dobijanja i procene dokaza vezanih za izjave uprave preduzeća o ekonomskim aktivnostima i događajima kako bi se odredio stepen saglasnosti između tih tvrdnji i ustanovljenih kriterijuma, a dobijeni rezultati preneli zainteresovanim korisnicima. Danas u svetu postoje tri osnovna modela organizovanja državne revizije kroz vrhovnu revizorsku instituciju:

- model suda, sa sudskim nadležnostima i ovlašćenjima,

- model suda, bez sudskih nadležnosti i ovlašćenja i

- sa glavnim - generalnim revizorom na čelu.

Model suda sa sudskim nadležnostima i ovlašćenjima predstavlja Vrhovnu revizorsku instituciju koja je organizovana kao kolegijalno telo po modelu suda, sa sudskim ovlašćenjima i nadležnostima koja se još naziva i Napoleonov model je najstariji model institucionalnog organizovanja Vrhovnih revizorskih institucija koji se pojavio početkom 19. veka u Francuskoj. Osnovne karakteristike funkcionisanja Vrhovnih revizorskih institucija organizovanih po ovom modelu su:

- na radnim mestima glavnih računovođa u ministarstvima i drugim institucijama javnog sektora raspoređene su računovođe iz Ministarstva finansija što Ministarstvo finansija čini još odgovornijim za stanje u javnom sektoru,

- glavne računovođe su nezavisne od institucija javnog sektora u kojima su raspoređene,

- Ministarsvo finansija utvrđuje propise i pravila po kojima postupaju sve glavne računovođe,

- revizorski sud - sud revizora godišnje sprovodi reviziju finansijskih izveštaja svih institucija javnog sektora i svih glavnih računovođa,

- $\quad$ sud revizora - revizorski sud godišnje izveštava Parlament, Vladu i Ministarstvo finansija o provedenim revizijama.

Model suda, bez sudskih nadležnosti i ovlašćenja predstavlja Vrhovnu revizorsku instituciju koja je organizovane kao kolegijalna tela po modelu suda, ali bez sudskih nadležnosti i ovlašćenja. Ovako organizovane revizorske institucije su organizaciono slične sudu, ali nisu po načinu funkcionisanja i nisu deo pravosudnog sistema, a revizori nemaju prava i obaveze sudija redovnih sudova. Na ovaj način organizovan je i funkcioniše Evropski revizorski sud, revizorska institucija Evropske unije. Osnovna obeležja Vrhovnih revizorskih institucija organizovanih na ovaj način su:

- za razliku od Vrhovnih revizorskih institucija na čelu sa glavnim revizorom, funkciju glavnog revizora obavlja kolegijalno telo - odbor,

- u odboru svi članovi odbora imaju isti status i sve odluke se donose konsenzusom,

29 Univerzitet za poslovne studije Banja Luka 
- pored odbora može se oformiti nekoliko pododbora i apelacioni odbor koji ima nadležnosti da arbitrira između pododbora,

princip donošenja odluka putem konsenzusa može biti spor i težak tako da se na taj način dovodi u pitanje efikasnost rada Vrhovne revizorske institucije.

Model suda suda sa glavnim - generalnim revizorom na čelu predstavlja Vrhovnu revizorsku instituciju na čelu sa glavnim - generalnim revizorom i naziva se i parlamentarni, monokratski ili anglosaksonski model organizovanja Vrhovnih revizorskih institucija. Ovaj model organizacije je najrasprostranjeniji, odnosno najviše Vrhovnih revizorskih institucija je organizovano na ovaj način. Osnovna karakteristika ovog modela organizovanja i razlika u odnosu na dva prethodna je što na čelu revizorske institucije nije kolegijalno telo već jedno lice, glavni - generalni revizor. Nadležnosti, prava i obaveze glavnog revizora po pravilu su regulisane ustavom ili zakonom koji uređuje materiju javnog sektora. Ovaj model organizacije je najviše usaglašen sa odredbama Limske deklaracije što će reći da je prisutan i najveći nivo nezavisnosti. Cilj međunarodnih standarda revizije je jednoobraznost revizorske prakse i sa njom povezanih usluga u cijelom svetu izdavanjem propisa za čitav niz revizorskih funkcija.

\section{MEĐUNARODNA FEDERACIJA RAČUNOVOĐA - INTERNATIONAL FEDERATION OF ACCOUNTANTS (IFAC)}

Međunarodna federacija računovođa (IFAC) je svetska organizacija za računovodstvenu profesiju. Osnovana je 1977. godine sa sedištem u Njujorku sa zadatkom da:

- služi javnom interesu,

- jača računovodstvenu profesiju na globalnom nivou i

- doprinese razvoju jake međunarodne ekonomije uspostavljanjem i promovisanjem profesionalnih standarda visokog kvaliteta, promovisanjem međunarodnog prihvatanja takvih standarda i rešavanjem pitanja od javnog interesa u kojima je profesionalna stručnost najrealnija ${ }^{30}$.

Međunarodnu federaciju računovođa (IFAC) sačinjava više od 175 organizacija ${ }^{31}$ iz svih krajeva sveta (iz 130 zemalja sveta koje predstavlja više od 2,5 miliona računovođa iz javne prakse, obrazovanja, javnog sektora, privrede i trgovine). Shodno Odboru za Međunarodne računovodstvene standard, svrha finansijskih izveštaja je da prezentuju informacije bitne za donošenje poslovnih odluka. lako su finansijski izveštaji element sadržaja svih računovodstvenih standard, ne bave se njima svi standardi na isti način i u istom obimu. Računovodstveni standardi koji se neposredno bave finansijskim izveštajima su:

- MRS 1 - Prezentacija finansijskih izveštaja,

- MRS 10 - Događaji posle datuma bilansa stanja,

- MRS 7 - Izveštaji o novčanim tokovima,

- MRS 14 - Izveštavanje po segmentima,

- MRS 27 - Konsolidovani i pojedinačni finansijski izveštaji,

- MRS 29 - Finansijsko izveštavanje u hiperinflatornim privredama,

- MRS 30 - Obelodanjivanje u finansijskim izveštajima banaka i sličnih finansijskih institucija,

- $\quad$ MRS 34 - Periodično finansijsko izveštavanje. ${ }^{32}$

Upravljanje Međunarodnom federacijom računovođa je u nadležnosti njegovog Odbora i Veća. Odbor je manja grupa odgovorna za uspostavljanje politike Međunarodne federacije računovođa, a veće uključuje po jednog predstavnika iz svake oragnizacije - članice. Glavne komponente IFAC-ovog okvira čine:

- Međunarodni standardi revizije i uveravanja (donosi ih, menja i ukida Odbor za međunarodne standarde i reviziju i uveravanja - IAASB),

- Etički kodeks za profesionalne računovođe (donosi ga i menja Komitet za etiku),

- Međunarodni obrazovni standardi (donosi in, menja i ukida Odbor za međunarodne računovodstvene standard edukacije - IAESB) $i$

- Međunarodni računovodstveni standardi za javni sektor (donosi ih, menja i ukida Komitet za javni sektor - odbor za međunarodne računovodstvene standard za javni sektor IPSASB).

\footnotetext{
30 Petrović Z., Međunarodni standardi revizije, Univerzitet Singidunum, Beograd,2010. (strana 7.)

31 http://www.ifac.org/about-ifac

32 dr Ljiljana Dmitrović Šaponja, Računovodstvo, Univerzitet u Novom Sadu, Subotica, 2010. (Strana 498.)
} 


\section{MEĐUNARODNI STANDARDI REVIZIJE - INTERNATIONAL STANDARDS ON AUDITING}

(ISA)

Međunarodni standardi revizije ${ }^{33}$ (ISA) se primenjuju pri reviziji finansijskih izveštaja opšte namene. Radi se o finansijskim izveštajima koji su odobreni za obelodanjivanje od strane uprave klijenta revizije. Međunarodni standardi revizije sadrže:

- osnovne principe (pravila) i suštinske postupke,

- relevantne smjernice u obliku objašnjenja i drugog materijala, što uključuje i dodatke.

Osnovne principe (pravila) i suštinske postupke treba tumačiti i primenjivati u kontekstu objašnjenja i drugog materijala koji sadrži smernice za primenu. Stoga je za razumevanje i primenu osnovnih principa i suštinskih postupaka neophodno razmatrati celokupan tekst konkretnog standarda. Priroda Međunarodnih standarda revizije zahteva od revizora profesionalno ponašanje prilikom njihove primene. U izuzetnim okolnostima profesionalni računovođa može da proceni da je neophodno da odstupi od osnovnih principa ili suštinskih postupaka standarda kako bi što efikasnije postigao cilj angažovanja. Kada do takve situacije dođe, profesionalni računovođa treba da bude spreman da opravda takvo odstupanje.

Svako ograničenje primenjivosti (delokrug) određenog Međunarodnog standard revizije jasno je naglašeno u samom standardu. Saopštenja o međunarodnoj praksi revizije (IAPS) se objavljuju radi pružanja smernica o interpretaciji i praktičnoj pomoći profesionalnim računovođama tj. revizorima $u$ pripremi Međunarodnih standarda revizije, kao i u cilju unapređenja dobre prakse revizije finansijskih izveštaja. Jedini nadležni tekst Međunarodnih standarda revizije, saopštenja o međunarodnoj praksi revizije, nacrta za izlaganje ili bilo kog drugog dokumenta je onaj koji je na engleskog jeziku objavio Odbor za međunarodne standarde revizije i uveravanja. IFAC daje pravo na prevod Međunarodnih standard revizije i Saopštenja o međunarodnoj praksi revizije. Odbor za međunarodne standard revizije i uveravanje doneo je Međunarodni okvir angažovanja na osnovu kojih pruža uveravanje i sledeće Međunarodne standarde revizije i Saopštenja o međunarodnoj praksi revizije:

1) Međunarodni standardi revizije

1. 200 Cilj i opšti principi revizije finansijskih izveštaja,

2. 210 Uslovi revizijskih angažovanja,

3. 220 Kontrola kvaliteta revizije finansijskih izveštaja,

4. 230 Revizorska dokumentacija,

5. 240 Odgovornost revizora za razmatranje kriminalnih radnji u reviziji finansijskih izveštaja,

6. 250 Razmatranja primjene zakona i drugih propisa u obavljanju revizije finansijskih izveštaja,

7. 260 Saopštenje revizijskih nalaza licima ovlašćenim za upravljanje,

8. 300 Planiranje revizije finansijskih izveštaja,

9. 315 Razumevanje pravnog lica i njegovog okruženja i procjena rizika materijalne greške,

10. 320 Materijalnost u reviziji,

11. 330 Revizorski postupci kao odgovor na procenjene rizike,

12. 402 Revizijska razmatranja u vezi s pravnim licima koja koriste uslužne organizacije,

13. 500 Revizijski dokaz,

14. 501 Revizijski dokaz - Dodatna razmatranja za specifične pozicije,

15. 505 Eksterne potvrde,

16. 510 Prva angažovanja - Početna stanja,

17. 520 Analitički postupci,

18. 530 Revizijsko uzrokovanje i drugi selektivni postupci provere,

19. 540 Revizija računovodstvenih procena,

20. 545 Revizija mjerenja i obelodanjivanja fer vrednosti,

21. 550 Povezani subjekti,

22. 560 Naknadni događaji,

23. 570 Načelo stalnosti pravnog lica,

24. 580 Izjave rukovodstva,

25. 600 Korištenje rezultata rada drugog revizora,

26. 610 Razmatranja rezultata rada interne revizija,

27. 620 Korištenje rezultata rada stručnjaka,

28. 700 Izveštaj nezavisnog revizora o setu finansijskih izveštaja opšte namene,

29. 701 Modifikacija izveštaja nezavisnog revizora,

33 Petrović S., Međunarodni standardi revizije, Univerzitet Singidunum, Beograd,2010. (strana 14.) 
30. 710 Uporedni podaci,

31. 720 Ostale informacije i dokumenti sadržani u finansijskim izveštajima koji su bili predmet revizije,

32. 800 Izveštaji revizora o revizijskim angažmanima za specijalne svrhe.

2) Saopštenja o međunarodnoj praksi revizije

33. 1000 Postupci međubankarskih konfirmacija,

34. 1004 Odnos između nadzornih institucija nad poslovanjem banaka i eksternih revizora,

35. 1005 Posebna razmatranja u vezi sa revizijom malih pravnih lica,

36. 1006 Revizija finansijskih izveštaja banaka,

37. 1010 Razmatranja pitanja u vezi životne sredine pri reviziji finansijskih izveštaja,

38. 1012 Revizija derivativnih finansijskih instrumenata,

39. 1013 Elektronska trgovina - Uticaj na reviziju finansijskih izveštaja i

40. 1014 Izveštavanje revizora o usklađenosti sa Međunarodnim standardima finansijskog izveštavanja.

\section{LIMSKA DEKLARACIJA}

Institucionalizacija revizije započeta je u Limi donošenjem deklaracije na IX kongresu INTOSAI 1977. godine. Glavni cilj Limske deklaracije ${ }^{34}$ je uspostavljanje i održavanje nezavisnosti Vrhovnih revizorskih institucija. Vrhovne revizorske institucije ne mogu opstati i funkcionisati ukoliko se ne uspostavi njihova nezavisnost. Ona ističe potrebu da se odredbe o nezavisnosti Vrhovnih revizorskih institucija inkorporiraju u registrativu o reviziji javnog sektora. Limska deklaracija sastoji se od sedam delova:

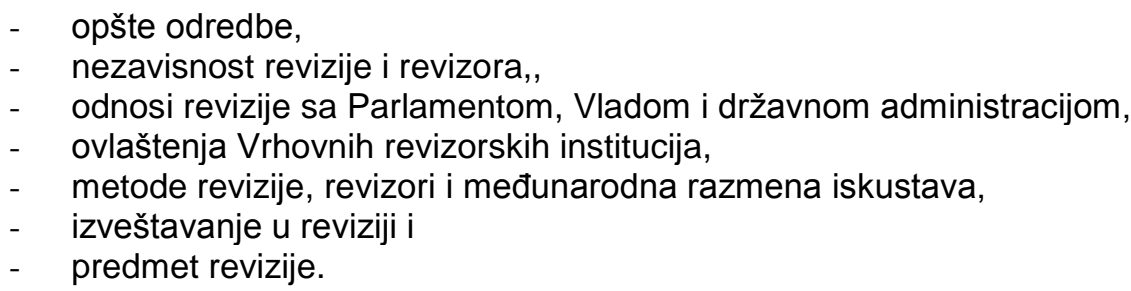

\subsection{Opšte odredbe}

Opšte odredbe govore o svrsi revizije javnog sektora i vrstama revizije u javnom sektoru. Kad je reč o svrsi revizije navodi se da revizija nije sama sebi cilj nego je dio ukupnog regulatornog sistema koji ima za cilj da otkriva devijacije u odnosu na usvojene standarde i kršenje principa legaliteta, racionalnosti, efikasnosti $i$ efektivnosti $u$ upravljanju finansijskim i drugim sredstvima, kako bi se omogućilo preduzimanje korektivnih mera i nateralo odgovorne da prihvate odgovornost kako bi se preduzeli koraci na sprečavanju ili otkrivanju takvih prekršaja. Kad je reč o vrstama revizije u javnom sektoru, Limska deklaracija razvrstava reviziju prema kriterijumu:

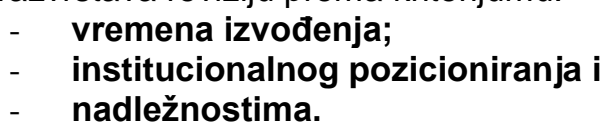

Prema vremenu i načinu implementiranja revizija može biti:

- prethodna i

- naknadna revizija (za razliku od revizije privatnog sektora koja je uvek naknadna revizija).

Prethodna revizija predstavlja pregled pre predstavljanja stanja, administrativnih i finansijskih aktivnosti, a naknadna revizija je revizija nakon predstavljanja stanja. Prethodna revizija ima prednost što može sprečiti nastajanje štete, ali joj je nedostatak što se u tom slučaju pred reviziju stavlja mnogo posla, a vrhovne revizorske institucije nemaju dovoljno resursa za obavljanje tih poslova. Naknadna revizija ne može spriječiti nastajanje štete, ali može uticati da se nastala šteta nadoknadi, sprečiti njeno ponavljanje i inicirati utvrđivanje odgovornosti za nastalu štetu.

\section{Prema institucionalnom pozicioniranju, Limska deklaracija razlikuje: \\ internu i \\ eksternu reviziju.}

${ }^{34}$ Milojević I., Budžetska revizija (prezentacija), Banja Luka, 2014. 
Interna revizija se organizuje u okviru organizacione strukture, a eksterna revizija organizuje se izvan organizacione strukture. Eksterna revizija organizuje se kao vrhovna revizorska institucija. Eksterna revizija između ostalog ima mandat da revidira rad interne revizije.

\section{Prema nadležnostima i predmetu revizije, Limska deklaracija razlikuje:}

- finansijsku reviziju (revizija završnog računa i revizija zakonitosti poslovanja) i reviziju učinka.

Istorijski i tradicionalno posmatrano vrhovne revizijske institucije orijentisane su ka finansijskoj reviziji - reviziji usklađenosti poslovanja, međutim perspektive razvoja revizije javnog sektora ukazuju da će vrhovne revizorske institucije u budućnosti biti orijentisane ka reviziji učinka.

\subsection{Nezavisnost revizije i revizora}

Odredbe o nezavisnosti podrazumevaju nezavisnost vrhovnih revizorskih institucija i revizora. Vrhovne revizorske institucije mogu ispuniti svoju ulogu samo ukoliko su nezavisne od institucija nad kojom sprovode reviziju i bilo kojih drugih uticaja. lako je teško ostvariti potpunu nezavisnost vrhovnih revizorskih institucija, od njih se očekuje da imaju organizacionu, funkcionalnu i finansijsku nezavisnost.

\subsection{Odnosi vrhovnih revizorskih institucija sa Parlamentom}

Odnosi vrhovnih revizorskih institucija sa Parlamentom se po pravilu regulišu najvišim normativnim aktima državnih entiteta. Posebno je bitan odnos vrhovnih revizorskih institucija i parlamentarnog odbora za pitanja revizije. Kada su u pitanju odnosi vrhovnih revizorskih institucija i Vlade i vladinih institucija, vrhovne revizorske institucije trebaju biti zaštićene od uticaja Vlade i vladinih institucija.

\subsection{Ovlaštenja Vrhovnih revizorskih institucija}

Ovlašćenja vrhovnih revizorskih institucija utvrđuju se normativnim aktima i podrazumevaju utvrđivanje predmeta, obima, metoda revizije, nesmetan pristup objektima, sredstvima, dosijeima, dokumentima i drugim podacima i informacijama bitnim za sprovođenje revizije i slobodno izveštavanje o obavljenoj reviziji.

\subsection{Metode revizije, revizori i međunarodna razmjena iskustava}

Odredbe o metodama rada, revizorima i međunarodnoj saradnji podrazumevaju da će vrhovne revizorske institucije reviziju sprovoditi u skladu sa planovima i programima revizije i da će slobodno i samostalno utvrđivati metode, tehnike i procedure revizije. Limska deklaracija ističe i potrebu za kvalifikacijama, motivacijom, edukacijom i moralnim integritetom revizora. Kada je u pitanju međunarodna saradnja preporučuje se razmena ideja i iskustava u okviru INTOSAl i regionalnih organizacija kao što je EUROSAl i određeni oblici biletaralne saradnje.

\subsection{Izveštavanje u reviziji}

Odredbe o izveštavanju tretiraju izveštavanje prema Parlamentu i javnosti. Vrhovne revizorske institucije su ovlašćene $i$ obavezne da o rezultatima revizije izveštavaju Parlament odnosno nadležni parlamentarni odbor. Izveštaj koji se dostavlja Parlamentu je javni izveštaj - javni dokument i dostupan je javnosti na načine i u formi kako je to uređeno normativnom regulativom.

\subsection{Predmet revizije}

Limska deklaracija navodi osnovna ovlašćenja vrhovnih revizorskih institucija, odnosno predmet revizije koji može biti:

- budžet na raznim nivoima,

- porezi,

- javni ugovori i javni radovi,

- revizija elektronske obrade podataka,

- revizija javnih preduzeća,

- revizija institucija sa subvencijama i

- revizija međunarodnih organizacija.

Prema napred navedenom deo revizije javnog sektora koji se sprovodi od strane vrhovne revizorske institucije odnosi se na budžetsku reviziju. 


\section{MEĐUNARODNA ORGANIZACIJA DRŽAVNE REVIZIJE - INTOSAI}

INTOSAI je osnovan 1953. godine u godine u Havani (Kuba) i imao je 34 članice koje su i bile osnivači. Vremenom broj članova se povećao na 192 članica ${ }^{35}$. INTOSAI podržava svoje članice u ostavrenju svoje misije uz mogućnost razmjene informacija i iskustava koje su stekli prilikom vršenja revizije u svojim zemljama. Osnovni moto kojim se vodi ova organizacija glasi: "Uzajamno iskustvo svima koristi" (lat: "Ehperimentia mutua omnibus prodest"). Godine 1992. na Kongresu u Vašingtonu usvojen je Statut INOSAI gdje je opisana struktura, članstvo, mandate i pravila delovanja. Takođe tada su usvojeni i Standardi revizije javnog sektora i Smernice za standard internih kontrola. INTOSAI izdaje smernice za finansijski menadžment i ostala srodna područija. Članstvo je otvoreno svim Vrhovnim revizorskim institucijama zemalja koje su članice Organizacije ujedinjenih nacija. ${ }^{36}$ INTOSAI Upravni odbor je prepoznao sledećih sedam regionalnih radnih grupa:

\subsection{Afrosai}

Glavni cilj afričke organizacije ${ }^{37}$ vrhovnih revizorskih institucija koja je osnovana u novembru 1976. godine.(AFROSAI) je da promoviše i razvija razmenu ideja $\mathrm{i}$ iskustava među revizorskim institucijama afričkih država u oblasti revizije javnih finansija i to:

- Implementacija sistematske studije u vezi revizije javnih finansija,

- Organizovanje obuke za radnike ovlašćene za obavljanje revizije,

- Saradnja sa INTOSAI, svojim regionalnim radnim grupama i drugim organizacijama i institucijama koje su specijalizovane za reviziju javnih finansija.

\subsection{Arabosai}

Ciljevi arapske organizacije ${ }^{38}$ vrhovnih revizorskih institucija (ARABOSAI) koja je osnovana 1976. godine obuhvataju:

- Podsticanje razmjene ideja, stavova, iskustava, studija i istraživanja među institucijama članicama u oblasti revizije i raditi na promociji revizije u naučnim i praktičnom smislu,

- Radi na podizanju svesti u arapskim narodima o važnosti revizije kako bi se ojačala uloga vrhovnih revizorskih institucija u obavljanju njenih zadataka,

- Organizovanje i jačanje saradnje između ARABOSAI i institucija i specijalizovanih organizacija arapskih država, INTOSAI, i drugim organizacijama kako međunarodnim i regionalnim čije aktivnosti se odnose na reviziju.

\subsection{Asosai}

Glavni cilj ASOSAl${ }^{39}$ je upoznavanje vrhovnih revizorskih institucija sa mogućnostima za obuku i kontinuirano obrazovanje za vladine revizora u potrazi za ciljem poboljšanja kvaliteta revizije i performanse. Od svog osnivanja ASOSAI je organizovao veliki broj programa. Teme ovih programa obuhvaćenih revizija u mnogim različitim oblastima, kao što su:

- finansijski i usklađenost,

- performanse i / ili vrednost-za-novac,

- računari / ili informacioni sistemi,

- javni radovi i

- privatizacija.

Ostali programi obuke usmereni na upravljanje ljudskim resursima za šefove i zamenike ASOSAI, upravljanje obukom, računovodstva troškova u vladi, i upravljanja budžetom. ASOSAI je osnovan 1979.

\subsection{Carosai}

Ciljevi Karibske organizacije ${ }^{40}$ vrhovnih revizorskih institucija (CAROSAI) obuhvataju sledeće: Promocija razmene ideja i iskustava u oblasti revizije vlade,

- Pružaju mogućnosti za obuku i kontinuirano obrazovanja,

- Promoviše značaj funkcije interne revizije u javnom sektoru,

\footnotetext{
${ }^{35} \mathrm{http}: / /$ www.intosai.org/about-us.html

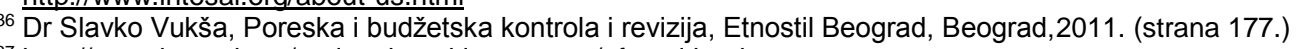

${ }^{37} \mathrm{http} / / / \mathrm{www}$.intosai.org/regional-working-groups/afrosai.html

38 http://www.intosai.org/regional-working-groups/arabosai.html

39 http://www.intosai.org/regional-working-groups/asosai.html

${ }^{40} \mathrm{http}: / /$ www.intosai.org/regional-working-groups/carosai.htm
} 
- Pružiti tehničku pomoć i razmjenu stručnosti među članovima,

- Podigne nivo svesti revizije u oblasti Kariba u cilju podrške institucijama koje obavljaju svoje dužnosti,

- Promovišu primenu sveobuhvatne revizije.

CAROSAI je uspostavila regionalni komitet za jačanje institucija (RISC), čiji je zadatak za pružanje efikasne $\mathrm{i}$ održive obuke te druge aktivnosti za izgradnju kapaciteta za regionalnu vrhovnu revizorsku instituciju. CAROSAl je osnovana 1988.

\subsection{Eurosai}

Glavni ciljevi evropske organizacije ${ }^{41}$ vrhovnih revizorskih institucija (EUROSAI) uključuju:

- Promovišu profesionalno saradnje među članovima vrhovnih revizorskih institucija,

- Podstakne razmenu informacija i dokumentacije,

- Unaprediti proučavanje revizije javnog sektora,

- Stimulisati stvaranje univerzitetskih profesora u ovoj oblasti,

- Raditi na usklađivanju terminologije u oblasti revizije.

Od samog početka EUROSAl je bio aktivan u organizovanju kvalitetne i obostrano korisne saradnje u oblasti revizije među svim zemljama ranije podeljene Evrope, prioritetnu podršku za osnivanje nezavisnih organa državne revizije u centralnoj i zemljama istočne Evrope u tranziciji. EUROSAl je osnovan 1990. godine.

\subsection{Olacefs}

Organizacija Latinske Amerike i Kariba ${ }^{42}$ vrhovnih revizorskih institucija (OLACEFS) je međunarodna, samostalna, nezavisna, organizacija. Njeni ciljevi su sledeći:

- Sprovesti naučno istraživanje,

- Razviti studije, obuke i specijalizacije,

- Pružiti tehničku pomoć, savete i koordinaciju za glavnog revizora Latinske Amerike i Kariba,

- Konceptualna vizija OLACEFS fokusira na promovisanju učešća različitim vrhovnim revizorskim institucijama u sopstvenom razvoju i unapređenju.

OLACEFS ima dugu tradiciju koja datira unazad do 1963. (predlog za osnivanje Latino Američkog instituta reviziji nauka (ILACIF) koji je realizovan u 1965.). Pod sadašnjim nazivom OLACEFS postoji od 1990. godine.

\subsection{Pasai}

Osnovni cilj Udruženja Pacifik ${ }^{43}$ vrhovnih revizorskih institucija (Pasai) je da uspešno sprovede svoj regionalni institucionalni plan jačanja. Plan ima pet ciljeva:

- Pomaganje vrhovnim revizorskim institucijama u treningu;

- Obezbeđivanjem načina deljenja informacija za obuku, metodologije i tehnologije u regionu;

- Obezbeđivanje relevantne obuke i sličnih aktivnosti;

- Obezbeđivanje neophodnih resursa za realizaciju plana;

- Promovisanje najbolje prakse i metodologije $\mathrm{i}$ jačanje vrhovnih revizorskih institucija. Specifični ciljevi ovog plana se sprovode od strane komiteta za jačanje regionalnih institucija (RISC).

Kao rezultat tog plana, održane su brojne radionice. Radionice su pokrile oblasti kao što su finansijska kontrola, nastup (vrednost-za-novac) revizije, tehničke instrukcije. Prvi radni kontakti između glavnog revizora u (Pacifičkom) području datiraju iz 1973. Formalno je prihvaćen kao regionalna radna grupa INTOSAI-ja 1987. godine.

\section{ZAKLJUČAK}

Sveukupni opšti cilj revizije je da omogući revizoru da izrazi mišljenje da su finansijski izveštaji u svim bitnim aspektima sačinjeni u skladu sa utvrđenim okvirom finansijskog izveštavanja tj. da daju istinit, fer i objektivan prikaz. Odredbe o nezavisnosti podrazumevaju nezavisnost vrhovnih revizorskih institucija i revizora. Vrhovne revizorske institucije mogu ispuniti svoju ulogu samo ukoliko su nezavisne od

\footnotetext{
${ }^{41}$ http://www.intosai.org/regional-working-groups/eurosai.htm

$42 \mathrm{http} / / /$ www.intosai.org/regional-working-groups/olacefs.html

$43 \frac{\text { http://www.intosai.org/regional-working-groups/pasai.html }}{2}$
} 
institucija nad kojim sprovode reviziju i bilo kojih drugih uticaja. lako je teško ostvariti potpunu nezavisnost vrhovnih revizorskih institucija, od njih se očekuje da imaju organizacionu, funkcionalnu i finansijsku nezavisnost. Da bi formirao i dao mišljenje revizor sprovodi revizorske postupke sa ciljem dobijanja dovoljno dokaza koji će podržati dato mišljenje. Dobijeni dokazi pružaju osnovu na bazi koje revizor formira svoje mišljenje. Da bi revizor dokazao da je izvršena revizija bila adekvatna, revizor mora pokazati da je imao adekvatan plan revizije, da je plan sproveden prema profesionalnim standardima, da je sakupljen dovoljan broj kompetentnih dokaza i da su svi upitni nalazi bili provereni. Priroda Međunarodnih standarda revizije zahtjeva od revizora profesionalno prosuđivanje prilikom njihove primjene. U izuzetnim okolnostima profesionalni računovođa može da proceni da je neophodno da odstupi od osnovnih principa ili suštinskih postupaka standarda kako bi što efikasnije postigao cilj angažovanja. Kada do takve situacije dođe, profesionalni računovođa treba da bude spreman da opravda takvo odstupanje.

\section{LITERATURA}

1. Petrović S., Međunarodni standardi revizije, Univerzitet Singidunum, Beograd,2010

2. Dmitrović Šaponja Lj., Petkovič Đ., Jakšić D., Računovodstvo, Univerzitet u Novom Sadu, Subotica, 2010.

3. Vukša S., Ristić Ž., Dinčić M., Belokapić P., Poreska i budžetska kontrola i revizija, Etnostil Beograd, Beograd, 2011.

4. Milojević I., Budžetska revizija (prezentacija), Banja Luka, 2014.

5. http://www.intosai.org/about-us.html

6. http://www.ifac.org/about-ifac

7. http://www.intosai.org/regional-working-groups/afrosai.html

8. http://www.intosai.org/regional-working-groups/arabosai.html

9. http://www.intosai.org/regional-working-groups/asosai.htmlhttp://www.intosai.org/regional-workinggroups/carosai.html

10.http://www.intosai.org/regional-working-groups/eurosai.html

11.http://www.intosai.org/regional-working-groups/olacefs.html

\section{APSTRAKT}

The theme of this article is to present the importance of international auditing standards, the provisions of the Lima Declaration, as well as the international organization of state audit (INTOSAI). Regional working groups are spread on all continents promote the objectives of INTOSAI in their regions, thus providing members the opportunity for professional and technical cooperation at the regional nivou.Da to the audit process successfully completed, with the expertise and training of auditors, require use of and adherence to standards audit.

Many states have laws on the public sector audit incorporate the provisions of the Lima Declaration, in the sense that it is the responsibility of the budget and performance audits of public companies. For example 24 countries within the European Union's laws on public sector auditing within the jurisdiction of the Supreme Audit Institutions put the audit of public companies.

Key words: Lima Declaration, The international auditing standards, spread on all continents, professional and technical cooperation 